\title{
GRIEF OF CHILDREN AT PRESCHOOL AGE
}

\author{
Heni Nur Anina \\ Hasan Sadikin Hospital Bandung-West Java Provincy-Indonesia \\ Email: heninuranina@gmail.com
}

\begin{abstract}
ABSTRAK
Berkabung adalah respon seseorang terhadap kehilangan. Pada anak-anak, efek dari kehilangan sama dengan pada dewasa, tapi anak-anak mengekspresiakan rasa duka mereka dengan yang cara berbeda dan hal ini sulit difahami oleh orang dewasa. Pemahaman anak-anak pada kematian tergantung pada usia dan tahap perkembangan mereka. Artikel ini membahas tentang berkabung (grief) pada anak usia prasekolah (2-5 tahun) mencakup perbedaan antara 'normal grief' dan 'complicated grief', gejala dari 'complicated grief', dan penatalaksanaan berkabung pada anak usia di kelompok usia ini. Pembahasan mengenai hal ini penting untuk meminimalisir efek dari berkabung. Efek berkabung pada anak di usia ini dapat berlanjut pada tahap perkembangan selanjutnya. Anak-anak yang berkabung dapat mengalami gejala emosi dan perilaku tertentu. Gejala-gejala tersebut dapat bertahan sampai remaja dan dewasa. Metode pencarian literatur secara komprehensif telah dilakukan dengan menggunakan piranti pencarian berbasis elektronik, yaitu: MEDLINE (EBSCO), CINAHL, Joanna Briggs Institute (Ovid), Proquest (Nursing and Allied Health Source), Pubmed, find@flinders, and Google Scholar. Perbedaan antara 'normal grief' and 'complicated grief' berkaitan dengan intensitas dan durasi berkabung. Penatalaksanaan berkabung pada anak usia prasekolah dapat menggunakan tehnik storytelling, creative arts, musik, dance/movement therapy, bermain, berinteraksi dengan anak menggunakan mainan dan games, melukis, melihat foto-foto, and memorabilia. Konsep 'kekekalan' dari kematian sangat sulit difahami oleh anak usia prasekolah. Mereka mungkin berpikir bahwa mendiang akan kembali. Selain itu, walaupun sesama anak usia prasekolah, namun setiap anak adalah unik. Maka, keefektifan dari penatalaksaan tergantung pada pilihan intervensi yang sesuai dengan anak tersebut. Memberikan kenyamanan secara fisik, memberikan dukungan emosional, komunikasi dan meyakinkan bahwa mereka disayangi dan tidak sendiri adalah poin-poin penting dalam penatalaksanaan berkabung pada anak usia prasekolah.
\end{abstract}

Kata kunci : Anak-anak, Berkabung, Usia prasekolah

\section{ABSTRACT}

Grief is someone's response to loss. In children, the effect of loss is identical with adults, but they express the grief differently and this is hard to be understood by adults. Children's understanding of death depends on their age and stage of development. This paper will discuss about grief of children at preschool age (2-5 years old) including the differences between 'normal grief' and 'complicated grief', the symptoms 'complicated grief', and the management. It is important to discuss grief of children at this age because the effect may progress to the next stage of development. Grieving children could suffer from certain emotional and behavioral symptoms that could persist into adolescent and adulthood. Method: a comprehensive literature search was conducted using electronic searching tools and databases: MEDLINE (EBSCO), CINAHL, Joanna Briggs Institute (Ovid), Proquest (Nursing and Allied Health Source), Pubmed, find@flinders, and Google Scholar.Discussion: The distinction between normal and complicated grief was related to the intensity and duration of the grief, and to the reactions having a negative functional impact on the child. Managing grief of preschool age children could be by storytelling, arts, music, dance/movement therapy, play, interact with the child by using toys and games, painting, old photos, and memorabilia. Conclusion: The permanency of death is a very difficult concept to grasp for children at preschool age. They may still think that the deceased will return. The effectiveness of the treatment is depending on the choice of interventions which appropriate for the child as each child is unique. Providing physical comfort, emotional support, communication and reassurance that they are cherished and not alone are the critical points in assessing grieving children at preschool age.

Keywords: Children, Grief, Preschool age 


\section{INTRODUCTION}

The impact of grief affects children is in similar ways to those of adults, but their expressions of grief are often different, and therefore easily misunderstood (D'Antonio, 2011; Lobb, Kristjanson, Aoun, \& Monterosso, 2006). Meanwhile, in terms of their capability to understand grief, Barnardos (2015) claimed that adults can understand about the grief, but children do not have the same level of understanding. Children's understanding of death depends on their age and stage of development (Barnardos, 2015; D'Antonio, 2011). Therefore, the age groups of children can help to classify the level of understanding of children about grief and this is important to determine the appropriate interventions (D'Antonio, 2011). Hensley and Clayton (2008) also noted that developmental phase of the child plays an essential role in how a child reacts to the loss of a loved one. In addition, Sood, Razdan, Weller \& RonaldWeller (2006) have stated that depending on their age and development, children may react to grief through new behaviors, including defiance and confusion.

This is because they may not yet have the cognitive and verbal skills to process their emotions (Sood, Razdan, Weller \& RonaldWeller, 2006). This paper will discuss about grief of children at preschool age (2-5 years old) and the treatments as well as recommendations to assess grieving children at preschool age.

In this age, the permanency of death is a very difficult concept to grasp (Barnardos, 2015). It is essential to discuss grief of children at this age group because the effects of grief may progress to the next stage of development (Cohen, Mannarino \& Deblinger, 2006). Children who experience loss of their love ones could suffer from certain emotional and behavioral symptoms. These symptoms could persist into adolescent and adulthood (Cohen, Mannarino \& Deblinger, 2006). Therefore, it is essential for parents, caregivers, and practitioners who working with grieving children to understand the manifestations of grief at this age to provide competent supports for the children (D’Antonio, 2011).

\section{METHOD}

A comprehensive literature search was conducted using electronic searching tools and databases: MEDLINE (EBSCO), CINAHL, Joanna Briggs Institute (Ovid), Proquest (Nursing and Allied Health Source), Pubmed, find@flinders (Flinders University) and Google Scholar. Key word combinations were used that referred to subject-specific keywords describing grief, children, preschool age, complicated grief, treatment, intervention, and management. The citations in this paper are in full-text and peerreviewed.

\section{DISCUSSION}

Grief is someone's response to loss (D'Antonio, 2011). Each person express grief uniquely and this is influenced by some factors such as age, previous exposure to loss and culture. It has been debatable whether children grieve. Some proponents stating that children do not grieve at all until they are adolescents, and others asserting that infants are also could experience grief (D'Antonio, 2011). The most common conclusion is children also do grieve of all ages, although their grief is expressed differently from adults (D'Antonio, 2011). Children's grief is also closely related to the stage of development. Children of varying ages are express grief differently (Barnardos, 2015; D'Antonio, 2011). Therefore, supporting a grieving child is relative to his or her stage of development (D’Antonio, 2011).

The permanency of death is a very difficult concept to grasp for children at preschool age (Barnardos, 2015). Children at this age may continue to believe that the dead person will return, that they are only away for a short time or that they can visit them (Barnardos, 2015; D'Antonio, 2011). 
Preschool-aged children are more likely to express their grief with repetitious questions, regression, irritability, and stomachaches (D’Antonio, 2011). They also experience anxiety regarding separation and express it in play and fantasy. For example, they may ask for a "replacement" of the loved one several months later (D'Antonio, 2011). They may be disappointed that the deceased does not reappear for their special occasions such as their birthday. They may become anxious about strangers or their caregiver leaving them, be clingy and need a lot of reassurance. Regressive behaviors, such as sleep disturbances, bed wetting and soiling are also common (Barnardos, 2015).

Lobb, Kristjanson, Aoun, \& Monterosso (2006) stated that the diagnostic term for complications that arise from grief has been variably defined, with a multitude of adjectives used to describe variations from normal grief. The similarities of normal and complicated grief may in cognitive, behavioral, emotional, psychological, and physical symptoms (Cohen, Mannarino \& Deblinger, 2006). The crucial point to distinguish normal grief and complicated grief in adults is time of the symptoms. Lobb, Kristjanson, Aoun, \& Monterosso (2006) explained that the criteria for diagnosing complicated grief includes the requirement that symptomatology persists for at least six months, regardless of when those six months occur in relation to the death. However, different with adults that the time to distinguish between normal and complicated grief is six months, there is no enough information that can explain about the time in children (Perkins \& Mackey, 2008). This is also supported by Dyregrov and KariDyregrov (2013), it is difficult to differentiate between normal grief and complicated grief in children.

There were some agreements that the distinction between normal and complicated grief was related to the intensity and duration of the grief, and to the reactions having a negative functional impact on the child (Dyregrov \& Kari- Dyregrov, 2013). In their study, Dyregrov and Kari-Dyregrov (2013) claimed that in complicated grief the child is usually preoccupied with the traumatic memories about what happened. The child can have difficulties in accepting the death, may have feelings of self-blame, anger, and lack of sense of safety. Nightmares and other sleeping difficulties may occur as well as overall regression. Complicated grief does not allow many comfortable or happy memories to exist until the traumatic memories have been processed (Dyregrov and KariDyregrov, 2013).

The specific symptoms that can be found in preschool children are: exaggerated fears, traumatic play, persistent regression, major disruptions in attachment with caregiver(s) (Dyregrov \& Kari-Dyregrov, 2013).

Perkins and Mackey (2008) also explained that when children exhibit a marked change in behaviors that persist over time, they may be experiencing 'complicated grief'. Behaviors that may indicate children have complicated grieving include: continuing tendencies of aggression or withdrawing which were not typical for the child before the grief, lasting changes in sleeping and eating patterns, and loss of interest and/or performance in daily activities (Perkins \& Mackey, 2008). McClatchey, Vonk, Lee, \& Bride (2014) argued that practitioners do need to be careful to assess for the presence of traumatic grief in any child who loses a parent or close loved one. McClatchey and Wimmer have explained that parentally bereaved children may lead to suicidal ideation, which makes it imperative to also examine existential symptoms in bereaved children (as cited in McClatchey, Vonk, Lee, \& Bride, 2014, p.77).

Managing grief of preschool age children by utilizing storytelling, creative arts, and dance/movement therapies are effective (Philpott, 2013). At the start of the 
intervention, it is crucial to know about the children's understanding about their grief. Storytelling can be used to explore their thoughts and feelings. Wong (2013) stated that at the beginning of therapy, it is important to identify the content of those losses and understand the emotions related to the issues by using storytelling. The telling story and the expression of feelings could also have helped to reinforce coping efforts of the child (Wong, 2013). Malchiodi (2008) argued that creative interventions with grieving children offer many benefits, including pleasure in making, doing, and inventing, play and imagination, and enhancement of self-worth through self-expression. Art, play, music, or movement can provide the necessary means to reenact the feelings and sensations associated with traumatic experiences. Webb (2003) noted that creative arts therapies have rationale in working with grieving children because feelings are often released more readily in non-verbal form. In their qualitative pilot study, dance/movement therapists Dillenbeck and Hammond-Meiers (2009) claimed that dance/movement therapy can work for children who grieve. Moreover, Webb has claimed that play therapy can be especially helpful with younger children during the grieving process as the caregiver can easily interact with the child by using toys and games (as cited in Phillpott, 2013, p.198). The other method is use art activities. Expressive arts activities like creative painting, old photos, and memorabilia offers opportunities to help explore hidden feelings and express grief emotions (Phillpott, 2013). The concepts of art therapy have been used for resolving her emotional problem through drawing the facial expression of the ginger cookies to express their grief emotions and pick up a color pen and drew a crying face because she felt sad and lonely (Phillpott, 2013).

The strategies to support the preschool age children who are experiencing grief include providing physical comfort and emotional support as well as reassurance (Tansey, 2008). At this stage of age, the children need repeated reassurance and security through verbal and physical affection and support (Tansey, 2008). The strategies are answering the children's questions about grief and loss clearly and honesty, letting them to talk about grief but not forcing conversations about their grief, not discussing details that may disturb or frighten children (particularly when they have not asked for this level of detail).

Furthermore, allowing plenty of time for children to engage in uninterrupted play and creative expression is also important. A part from that, the parents or other caregivers need to be ready if the children become distressed, destructive or aggressive towards others, therefore, assist them to find a way to express or relieve their feelings appropriately (Tansey, 2008). Moreover, Perkins and Mackey (2008) claimed that the grieving children can be referred to the most appropriate community services. The grieving children can also get an assistance from specific therapist such as creative art and dance/movement therapists. The child also could be assisted by a psychologist or psychiatric doctor. Further, bereavement and grief center could be an option for assistance. In Australia, for instance, The Australian Centre for Grief and Bereavement. The service provides a statewide specialist bereavement service for individuals, children and families who need assistance following the death of someone close to them. Counsellors at the service come from a variety of disciplines including social work, psychology and psychotherapy (The Australian Centre for Grief and Bereavement, 2015).

It is essential that the parents or other caregivers to do a sound communication with the children regarding the death of their loved one. D'Antonio (2011) explained that it is all right for the parents and caregivers to cry in front of the child, however, they should 
explain to the child about the reason for the tears. If possible, by simply saying that the sadness and crying and is because the deceased will never be seen anymore. It is best not to lament, but if this is the cultural norm, then an explanation to the child is even more essential (D'Antonio, 2011). It is not wise to hiding grief, since children sense it anyhow, and a direct explanation prevents them from drawing incorrect conclusions regarding the cause of grief (D'Antonio, 2011). It is vital to constantly assure the children that they did not cause the death or grief. It is very common for them to believe that their bad behavior was the cause (D’Antonio, 2011). Moreover, their continual questions are a developmentally appropriate response, and adults should listen and answer patiently. Euphemisms and abstractions are not advisable (D'Antonio, 2011). Telling a child that the deceased is "sleeping" could cause the child to fear going to bed (D'Antonio, 2011). It is best to use the terms dead and death, especially if accompanied by an explanation such as dead means the deceased parent cannot eat or play anymore (D'Antonio, 2011). This helps the child begin to understand the non-functionality of death. At the same time, reinforcing the permanency of death can be included, since this is also an aspect of death that children at this age difficult to grasp (Barnardos, 2015; D'Antonio, 2011). The other approach to explain death to children at this age is using 'physical reason'. Hames have explained that providing a physical reason for the death, such as "their heart stopped working" is advisable and adding that this cannot happen to the child because his or her heart is not sick, as children may wonder if the same thing could happen to them (as cited in D'Antonio, 2011, p.19). Moreover, the children should be reassured that most illnesses are not serious, so they will not fear going to see a doctor (D’Antonio, 2011).

A decision to bring a child of this age to the funeral should be made sensitively on an individual basis (D'Antonio, 2011). Leaving the child at home can add to any existing feelings of abandonment, whereas attending the funeral can be upsetting if an intense emotional environment is expected (D'Antonio, 2011). Hames also stated that careful analysis and communication is imperative, and a reasonable alternative is to allow the child to attend the funeral but regarding grief of children at preschool age specifically based on grief exposure. The other limitation is the treatments that have been discussed were come from different places which may prevent these treatments to be applied to preschool age children in other settings and areas.

Further studies regarding grief of children at preschool age specifically regarding loss of their parents and/or siblings/relatives are needed. This is because the children's respond of loss may be different regarding different loss exposures. Then, this may lead to diverse possible management for assessing the children who experience grief.

\section{CONCLUSION}

The permanency of death is a very difficult concept to grasp for children at preschool age. They may still think that the deceased will return. Even though the children in this age group, however, each child is unique. Therefore, the effectiveness of the treatment is depending on the choice of interventions which appropriate for the child. Providing physical comfort, emotional support, communication and reassurance that they are cherished and not alone are the critical points in assessing grieving children at preschool age.

\section{REFERENCES}

Dillenbeck, M., \& Hammond-Meiers, J. (2009). Death and Dying: Implications for Dance/Movement Therapy. American Journal of Dance Therapy, 31(2), 95121. Retrieved from http://link.springer. 
com.ezproxy.flinders.edu.au/article/10.1 007/s10465-009-9074-2.

Dyregrov, A., \& Dyregrov, K. (2013). Complicated grief in children-the Perspectives of experienced professionals, Omega, 67, 3, 291-303. viewed 3 November 2015, Retrieved from http://ome.sagepub.com.ezproxy.flinder. edu.au/content/67/3/291.full.pdf $+h t m l$.

D'Antonio, J. (2011). Grief and Loss of a Caregiver in Children: A Developmental Perspective. Journal of Psychosocial Nursing \& Mental Health Services, 49(10), 17-20. Retrieved from http://search.proquest.com.ezproxy.flind ers.edu.au/docview/896875744?OpenUrl RefId=info:xri/sid:primo\&accountid $=10$ 910.

Fearnley, R. (2010). Death of a parent and the children's experience: Don't ignore the elephant in the room. Journal of Interprofessional Care, 24(4), 450-459. Retrieved from http://www.tandfonline. com/doi/abs/10.3109/135618209032748 71.

Hensley, P. L., \& Clayton, P. J. (2008). Bereavement: Signs, symptoms, and course. Psychiatric Annals, 38(10), 649654. Retrieved from http://search. proquest.com.ezproxy.flinders.edu.au/do cview/217057180?rfr_id=info\%3Axri\%2 Fsid\%3Aprimo.

Judith, A., Cohen., Anthony, P., \& Mannarino, E. D. (2006). Treating Trauma and Traumatic Grief in Children and Adolescents. New York: The Guilford Press.

Lobb, E. A., Kristjanson, L. J., Aoun, S., \& Monterosso, L. (2006). An Overview of Complicated Grief Terminology and Diagnostic Criteria. Grief Matters: The Australian Journal of Grief and Bereavement, 9(2), 28-32. Retrieved from http://espace.library.curtin.edu.au/ $\mathrm{R} /$ ?func $=$ dbin-jump-full\&object_id $=$ 20162\&local_base $=$ gen01-era02.
Malchiodi, C. A. (2008). Creative Interventions with Traumatized Children, London: Guildford Press.

McClatchey, I. S., Vonk, M. E., Lee, J., \& Bride, B. (2014), Traumatic and Complicated Grief Among Children: One or Two Constructs? Death Studies, 38(2), 69-78. Retrieved from http:// www.ncbi.nlm.nih.gov/pubmed/2451770 4.

McClatchy, I. S., Vonk, M. E., \& Palardy, G. (2009). The prevalence of childhood traumatic grief--A comparison of violent/sudden and expected loss. Omega, 59, 305-323. Retrieved from http://ome.sagepub.com/content/59/4/30 5.full.pdf + html

Perkins, K. D., \& Mackey, B. (2008). Supporting Grieving Children in Early Childhood Programs. NCAC, 36(3), 1318, Retrieved from http://www. southernearlychildhood.org/upload/pdf/S upporting_Grieving_Children_in_Early_ Childhood_Programs_Kaarin_D_Perkins and_Bonnie_Mackey_Vol_36_No_1.pdf.

Philpott, E. (2013). Moving Grief: Exploring Dance/Movement Therapists Experiences and Applications with Grieving Children, Am J Dance Ther, 142-168, Retrieved from http://link.springer.com/ article/10.1007\%2Fs10465-013-9158$\mathrm{x} \# /$ page-1.

Sood, A., Razdan, A., Weller, E., \& Weller, R. (2006). Children's reactions to parental and sibling death. Current Psychiatry Reports, 8(2), 115-120. Retrieved from http://link.springer.com/ article/10.1007/s11920-006-0008-0.

Tansey, S. (2008). Supporting Children through Loss and Grief, Putting Children First-National Childcare Accreditation Council, 22-25. Retrieved from http:// ncac.acecqa.gov.au/educator-resources/ pcf-articles/Supporting_children_through grief_and_loss_Sep08.pdf.

The Australian Centre for Grief and Bereavement. (2015). Grief and 
Bereavement Support. (online). Retrieved from http://www.grief.org. au/grief_and_bereavement_support.

Webb, N. B. (2003). Play and Expressive Therapies to Help Bereaved Children: Individual, Family, and Group Treatment, Smith College Studies in Social Work, 73(3), 405-422. Retrieved from http://www.tandfonline.com.ezproxy. flinders.edu.au/doi/abs/10.1080/0037731 0309517694.
Wong, F. K. C. (2013). Helping a Child Cope with Loss by Using Grief Therapy. Discovery - SS Student E-Journal,

2,195-215. Retrieved from http://ssweb. cityu.edu.hk/download/RS/EJournal/Vol2/journal10.pdf. 